\title{
Fabricating energy devices with low environmental impacts
}

\begin{abstract}
Massimo Innocenti, Francesco Di Benedetto, Alessandro
\end{abstract} Lavacchi, Nicola Cioffi, Roberto Felici, and Luca A. Pardi

Techniques such as electrochemical atomic layer epitaxial deposition can be used to grow high-quality pseudo-2D layers of photovoltaic materials.

Efforts to reduce the rate of carbon emissions from industry, ${ }^{1}$ as well as the impending economic and social problems that could arise from the depletion of fossil fuels, ${ }^{2}$ are the two driving forces for the development of devices that can generate electric power from renewable sources. It is necessary for research and development in this field to satisfy a few major requirements. In the last few decades, the increasing demand for high-tech applications has led to increasing solicitation of mineral deposits and has brought many rare metals to the brink of irreversible depletion. ${ }^{3}$ It is therefore necessary for new devices to be based on abundant materials that are available on a global or local scale. The whole 'life cycle' of the materials must also be environmentally friendly (i.e., the materials must be non-toxic and easily recycled). Moreover, the materials must be energetically favorable, i.e., they must involve low-energy consumption processes during all the phases of the life cycle (production, to maintenance, to decommission, to recycling). This final aspect-which can be determined accurately through a full life cycle assessment (LCA) - depends on the energy costs and energy conversion efficiency of the device itself. In a full LCA, several parameters are estimated. These include the payback time (time required to earn the energy costs of the production process), the energy return on energy investment (ratio between the energy produced by and the energy costs of the system along the whole life cycle), ${ }^{4}$ and the net energy (the energy delivered to society for discretionary uses after all the energetic costs are subtracted from the energy produced). This last figure of merit (i.e., the net energy) is a crucial parameter for defining energy policy. ${ }^{4}$

All these requirements for renewable energy devices can be met satisfactorily by solar cells that are based on pseudo-ternary sulfides, such as stannite $\left(\mathrm{Cu}_{2} \mathrm{FeSnS}_{4}\right)$, kuramite $\left(\mathrm{Cu}_{3} \mathrm{SnS}_{4}\right)$, and kesterite $\left(\mathrm{Cu}_{2} \mathrm{ZnSnS}_{4}\right) .{ }^{5}$ Kesterite-type semiconductors are

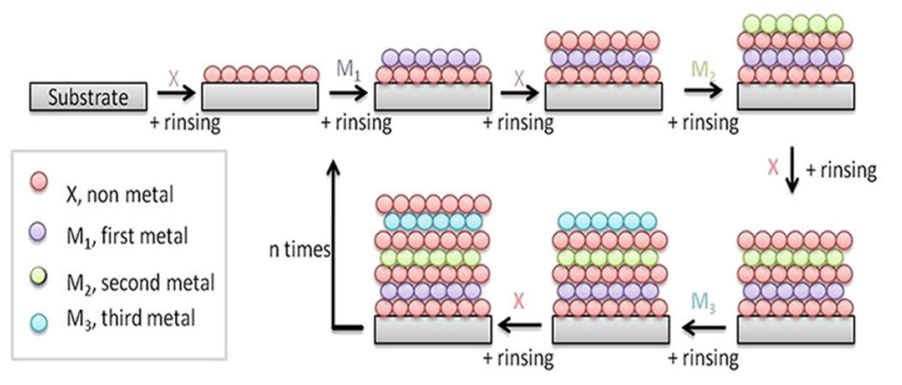

Figure 1. Schematic illustration of the electrochemical atomic layer epitaxial deposition (ECALE) technique for the growth of quaternary metallic compound thin films.

generally synthesized by high-temperature solidification, in the vapor phase, or under high-vacuum conditions. Other easier and cheaper methods (e.g., from aqueous solutions), however, can also be considered. Electrochemical techniques, for example, are particularly suitable for satisfying the requirements. Indeed, with these methods, a low cost can be achieved with relatively simple instrumentation, low working temperatures, and accurate control of the experimental parameters. ${ }^{6}$ Furthermore, morphological, structural, and compositional control of the final deposited film can be obtained.

In our work, we use a particular electrochemical techniqueknown as electrochemical atomic layer epitaxial deposition (ECALE) - to manufacture high-quality monolayers and multilayers of metal sulfide materials. With ECALE, we can exploit the underpotential deposition (UPD) methodology (i.e., the property of some materials to be deposited as a monolayer before massive electrochemical deposition). In addition, ECALE allows the composition, morphology, and structure of an aqueous solution at low temperature to be controlled. When the growth from ECALE-either from UPD processes or from any surface limited reaction-cannot be rigorously considered as epitaxial, it can be referred to as electrochemical atomic layer deposition (E-ALD). The major goal of our research is to demonstrate that 
ECALE can be used to efficiently fabricate high-quality monolayers and multilayers of pseudo-2D materials.

We grow the compound materials on metallic surfaces by depositing (using the UPD process) alternating monolayers of the different components (see Figure 11. We are also involved in developing a method to grow homostructures (i.e., monolayer and multilayers) and heterostructures (multilayers made of different layers of pseudo-2D materials). These techniques are being optimized in several laboratories. Indeed, we have used ECALE to successfully obtain a number of binary and ternary semiconductor thin films. These compounds include cadmium sulfide $(\mathrm{CdS}),{ }^{7-11}$ cadmium telluride $(\mathrm{CdTe}),{ }^{12}$ cadmium selenide (CdSe) ${ }^{13}$ zinc sulfide (ZnS), ${ }^{14}$ zinc selenide (ZnSe) ${ }^{14}$ nickel sulfide (NiS) ${ }^{15}$ lead sulfide (PbS), ${ }^{16-18}$ copper sulfide (CuS), ${ }^{19,20}$ and indium arsenide (InAs). ${ }^{21}$

A specific need in our field of work is for the structural characterization-with the use of opportunistic analytical techniques - of the ultra-thin films that are obtained from the electrochemical deposition techniques. We have thus performed in situ surface $x$-ray diffraction (SXRD) measurements to investigate the growth of CuS films. We conducted our experiments at the ID03 beamline at the European Synchrotron Radiation Facility in Grenoble, France. In these tests, we monitored the growth of the film by examining the evolution of the Bragg peaks

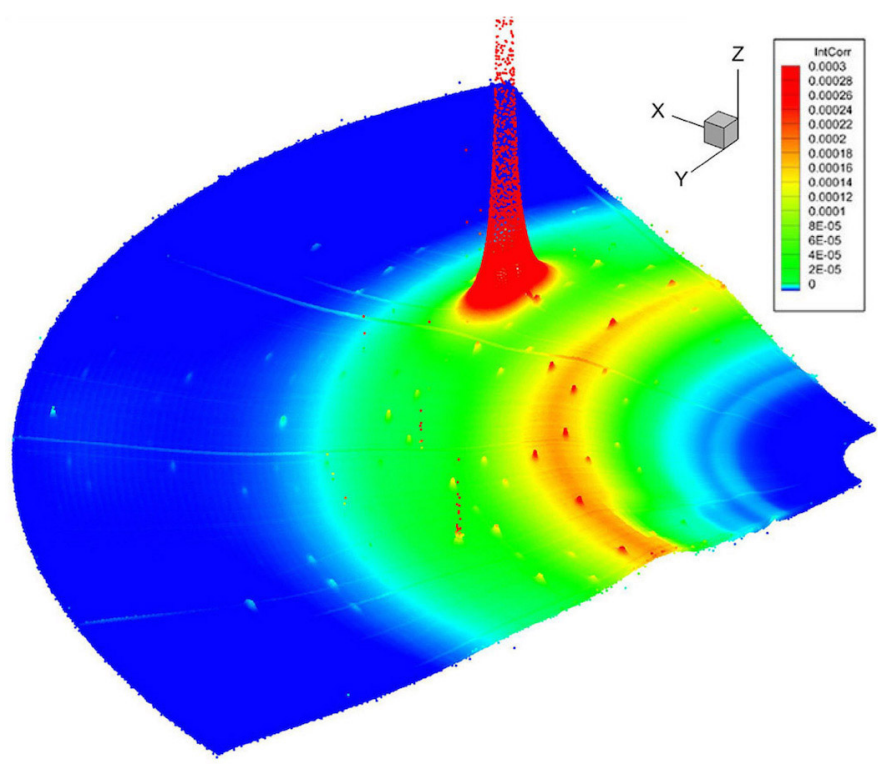

Figure 2. Results from surface $x$-ray diffraction measurements of a copper sulfide film. The 2D intensity map illustrates the reciprocal space where the Bragg reflections of the sample and the reference silver substrate are apparent. The self-standing film is clearly indicated by the high-intensity peak. after each E-ALD step. The results of our SXRD measurements are illustrated in Figure 2 These highlight the occurrence of a self-standing film, with a definite crystal structure, after $15 \mathrm{E}$ ALD cycles. After the first observation of the Bragg reflections, we registered only minor subsequent changes to the structural arrangement of the film.

We also conducted additional SXRD measurements to monitor the influence of the applied electric potential on the stability of the electro-deposited crystal structure. We performed these SXRD measurements during the switch-off of the potential. Our results showed that a structural change was indeed registered. Furthermore, we found that this structural change was correlated with the occurrence of the stable phases under conventional laboratory conditions.

Our research involves the use of the ECALE deposition technique for the growth of ultra-thin films of metal sulfide, ${ }^{22-25}$ and other, materials. So far we have been able to successfully develop several films of materials, including CdS, CdTe, CdSe, $\mathrm{ZnS}, \mathrm{ZnSe}, \mathrm{NiS}, \mathrm{PbS}, \mathrm{CuS}$, and InAs. Such films can be used for the manufacture of semiconductors for solar cells. Our electrochemical approach can meet the requirements for low-cost and efficient fabrication methods. We have also experimentally demonstrated that SXRD can be used to successfully characterize the structure of the fabricated films. ${ }^{26,27}$ Our future research will be aimed primarily at the construction of an entire solar cell, as well as electrodeposition of $\mathrm{p}$ and $\mathrm{n}$ semiconductors via the E-ALD technique.

\section{Author Information}

\section{Massimo Innocenti \\ Department of Chemistry \\ University of Florence \\ Florence, Italy}

\section{Francesco Di Benedetto}

Department of Earth Sciences

University of Florence

Florence, Italy

\author{
Alessandro Lavacchi \\ Institute of Chemistry of Organometallic Compounds (ICCOM), \\ CNR \\ Sesto Fiorentino, Italy
}




\section{Nicola Cioffi}

Department of Chemistry

University of Bari Aldo Moro

Bari, Italy

\section{Roberto Felici}

European Synchrotron Radiation Facility

Grenoble, France

\section{Luca A. Pardi}

Institute for Chemical and Physical Processes (IPCF), CNR Pisa, Italy

\section{References}

1. http://www.ipcc.ch/report/ar5/wg3/ Intergovernmental Panel on Climate Change report 2014: mitigation of climate change. Accessed 24 November 2015

2. C. J. Campbell, The oil age in an historical perspective, Oil Age 1, pp. 1-9, 2015.

3. P. Bihouix and B. de Guillebon, Quel futur pour les métaux?, p. 300, EDP Sciences, 2010.

4. C. Hall and K. Klitgaard, Energy and the Wealth of Nations, p. 424, Springer, 2012.

5. S. Schorr, Structural aspects of adamantine like multinary chalcogenides, Thin Solid Films 515, pp. 5985-5991, 2007.

6. D. Lincot, Electrodeposition of semiconductors, Thin Solid Films 487, pp. 40-48, 2005.

7. M. L. Foresti, G. Pezzatini, M. Cavallini, G. Aloisi, M. Innocenti, and R. Guidelli, Electrochemical atomic layer epitaxy deposition of CdS on $\mathrm{Ag}$ (111): an electrochemical and STM investigation, J. Phys. Chem. B 102, pp. 7413-7420, 1998.

8. T. Cecconi, A. Atrei, U. Bardi, F. Forni, M. Innocenti, F. Loglio, M. L. Foresti, and G. Rovida, X-ray photoelectron diffraction (XPD) study of the atomic structure of the ultrathin CdS phase deposited on Ag(111) by electrochemical atomic layer epitaxy (ECALE), J. Electron Spectrosc. Relat. Phenomena 114-116, pp. 563-568, 2001.

9. M. Innocenti, S. Cattarin, M. Cavallini, F. Loglio, and M. L. Foresti, Characterisation of thin films of CdS deposited on Ag(111) by ECALE. A morphological and photoelectrochemical investigation, J. Electroanal. Chem. 532, pp. 219-225, 2002.

10. M. Cavallini, M. Facchini, C. Albonetti, F. Biscarini, M. Innocenti, F. Loglio, E. Salvietti, G. Pezzatini, and M. L. Foresti, Two-dimensional self-organization of CdS ultra thin films by confined electrochemical atomic layer epitaxy growth, J. Phys. Chem. C 111, pp. 1061-1064, 2007.

11. E. Salvietti, F. Loglio, M. Innocenti, M. Cavallini, M. Facchini, G. Pezzatini, R. Raiteri, and M. L. Foresti, Patterned growth of CdS by combined electrochemical atomic layer epitaxy and microcontact printing techniques, Electrochim. Acta 52, pp. 60346040, 2007.

12. F. Forni, M. Innocenti, G. Pezzatini, and M. L. Foresti, Electrochemical aspects of CdTe growth on the face (111) of silver by ECALE, Electrochim. Acta 45, pp. 3225-3231, 2000.

13. F. Loglio, M. Innocenti, F. D'Acapito, R. Felici, G. Pezzatini, E. Salvietti, and M. L. Foresti, Cadmium selenide electrodeposited by ECALE: electrochemical characterization and preliminary results by EXAFS, J. Electroanal. Chem. 575, pp. 161-167, 2005.

14. M. Innocenti, G. Pezzatini, F. Forni, and M. L. Foresti, CdS and ZnS deposition on Ag(111) by electrochemical atomic layer epitaxy, J. Electrochem. Soc. 148, pp. C357C362, 2001.

15. G. Pezzatini, S. Caporali, M. Innocenti, and M. L. Foresti, Formation of ZnSe on Ag(111) by electrochemical atomic layer epitaxy, J. Electroanal. Chem. 475, pp. 164$170,1999$.

16. F. Loglio, M. Innocenti, A. Jarek, S. Caporali, I. Pasquini, and M. L. Foresti, Nickel sulfur thin films deposited by ECALE: electrochemical, XPS, and AFM characterization, J. Electroanal. Chem. 638, pp. 15-20, 2010.

17. V. C. Fernandes, E. Salvietti, F. Loglio, M. Innocenti, L. Mascaro, and M. Foresti, Electrodeposition of PbS multilayers on Ag(111) by ECALE (electrochemical atomic layer epitaxy), ECS Trans. 11, pp. 279-286, 2007.

18. V. C. Fernandes, E. Salvietti, F. Loglio, E. Lastraioli, M. Innocenti, L. H. Mascaro, and M. L. Foresti, Electrodeposition of PbS multilayers on Ag(111) by ECALE, J. Appl. Electrochem. 39, pp. 2191-2197, 2009.
19. M. Innocenti, I. Bencistà, S. Bellandi, C. Bianchini, F. Di Benedetto, A. Lavacchi, F. Vizza, and M. L. Foresti, Electrochemical layer by layer growth and characterization of copper sulfur thin films on $\operatorname{Ag}(111)$, Electrochim. Acta 58, pp. 599-605, 2011.

20. I. Bencistà, F. Di Benedetto, M. Innocenti, A. De Luca, G. Fornaciai, A. Lavacchi, G. Montegrossi, et al., Phase composition of $\mathrm{Cu}_{x} S$ thin films: spectroscopic evidence of covellite formation, Eur. J. Mineral. 24, pp. 879-884, 2012.

21. M. Innocenti, F. Forni, G. Pezzatini, R. Raiteri, F. Loglio, and M. L. Foresti, Electrochemical behavior of As on silver single crystals and experimental conditions for InAs growth by ECALE, J. Electroanal. Chem. 514, pp. 75-82, 2001.

22. F. Di Benedetto, I. Bencistà, S. Caporali, S. Cinotti, A. De Luca, A. Lavacchi, F. Vizza, M. M. Miranda, M. L. Foresti, and M. Innocenti, Electrodeposition of ternary $C u_{x} S n_{y} S_{z}$ thin films for photovoltaic applications, Prog. Photovolt. 22, pp. 97-106, 2014.

23. M. Innocenti, L. Becucci, I. Bencistà, E. Carretti, S. Cinotti, L. Dei, F. Di Benedetto, et al., Electrochemical growth of $\mathrm{Cu}-\mathrm{Zn}$ sulfides, J. Electroanal. Chem. 710, pp. 17-21, 2013.

24. M. Innocenti, S. Cinotti, I. Bencistà, E. Carretti, L. Becucci, F. Di Benedetto, A Lavacchi, and M. L. Foresti, Electrochemical growth of $\mathrm{Cu}-\mathrm{Zn}$ sulfides of various stoichiometries, J. Electrochem. Soc. 161, pp. D14-D17, 2014.

25. S. Caporali, A. Tolstogouzov, O. M. N. D. Teodoro, M. Innocenti, F. Di Benedetto, S. Cinotti, R. A. Picca, M. C. Sportelli, and N. Cioffi, Sn-deficiency in the electrodeposited ternary $C u_{x} S n_{y} S_{z}$ thin films by ECALE, Solar Energy Mater. Solar Cells 138, pp. 9-16, 2015.

26. F. Carlà, F. Loglio, A. Resta, R. Felici, E. Lastraioli, M. Innocenti, and M. L. Foresti, Electrochemical atomic layer deposition of CdS on Ag single crystals: effects of substrate orientation on film structure, J. Phys. Chem. C 118, pp. 6132-6139, 2014.

27. F. Di Benedetto, S. Cinotti, F. D'Acapito, F. Vizza, M. L. Foresti, A. Guerri, A Lavacchi, et al., Electrodeposited semiconductors at room temperature: an $x$-ray absorption spectroscopy study of $\mathrm{Cu}^{-}, \mathrm{Zn}$-, S-bearing thin films, Electrochim. Acta 179, pp. 495 503,2015 